\title{
FLOODINGS AND SOCIAL VULNERABILITY: THEIR SPACIAL EQUIVALENCE IN THE CITY OF CURITIBA, BRAZIL*
}

\author{
Clovis Ultramari*** \\ Pontifical University of Parana, Curitiba, Brazil. \\ Beatriz Hummell*****
}

Recibido: 31 enero 2013

Aprobado: 3 abril 2013

Botanical Garden, Curitiba. Source: Authors archive, Beatriz Hummell, 2013

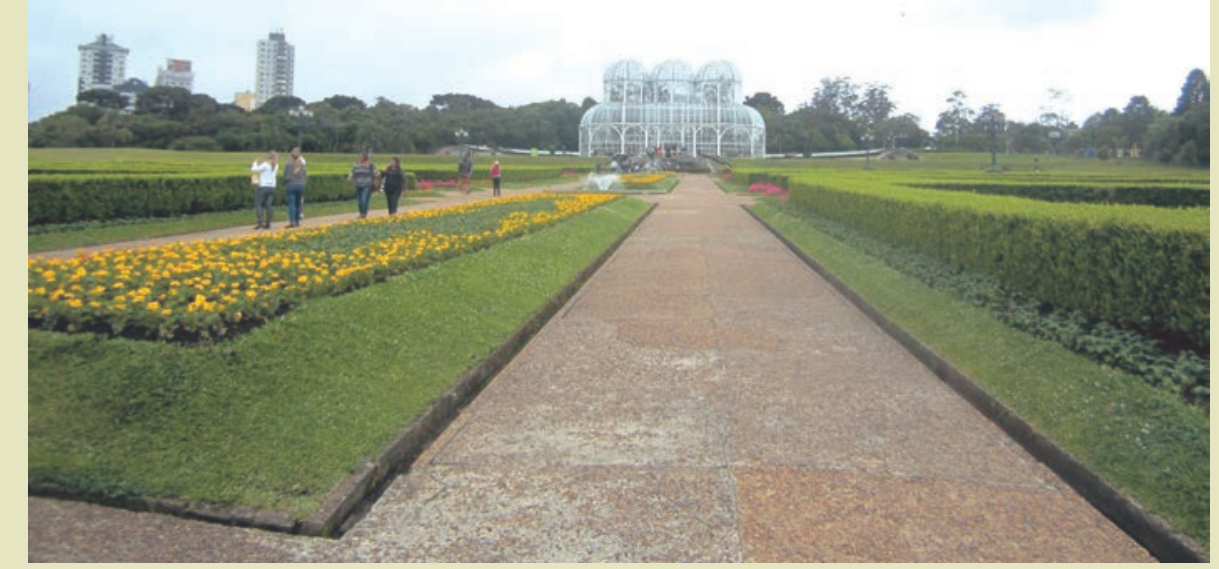

* Both authors live, work and research the city of Curitiba since they started their professional works. Research was developed as part of the Urban Management Post graduation Program, at the Pontifical University of Paraná. This paper represents the first step of a now long broader research concerning disaster occurring in cities. Current authors attention concerns the international flux of aid for emergency situations and the impacts of such situations in the local efforts for recovery.

* Clovis Ultramari is a professor at the Pontifical University of Parana, Curitiba, Brazil. His main areas of interest and research are land use legislation, natura accidents and their impacts on urban land use, assessment of large urban projects, and conceptual aspects of the city. He has written many articles and books on these subjects, mostly in Portuguese. He also serves as an advisor on dissertations and theses concerning his areas of expertise. His current research project is focused on the role of international aid agencies in disaster recovery action.

\begin{abstract}
This is a theoretical discussion on social vulnerability and on the construction of vulnerability indexes. Empirical exercise takes place in the city of Curitiba, Southern Brazil. Article is based on both conceptual approaches revealing complexity of such topic as well as on empirical demands to establish priorities in terms of risk reduction action facing natural adverse events and distribution of resources in post-disaster recovery. Urban context is that of Brazilian cities, revealing recurrent inequalities in the way inhabitants build, use, and transform urban compartments. Research presented here can be contextualized in a scenario where adverse phenomena should deeply influence the elaboration of urban public policies. Its main target is to contribute to the identification of parameters to channel public resources in preparedness actions facing adverse situations.
\end{abstract}

\section{KEYWORDS}

Social Vulnerability; Natural Hazards; Vulnerability Index; City of Curitiba. 


\section{LAS INUNDACIONES Y LA VULNERABILIDAD SOCIAL: SU ESPACIO DE EQUIVALENCIA EN LA CIUDAD DE CURITIBA, BRASIL}

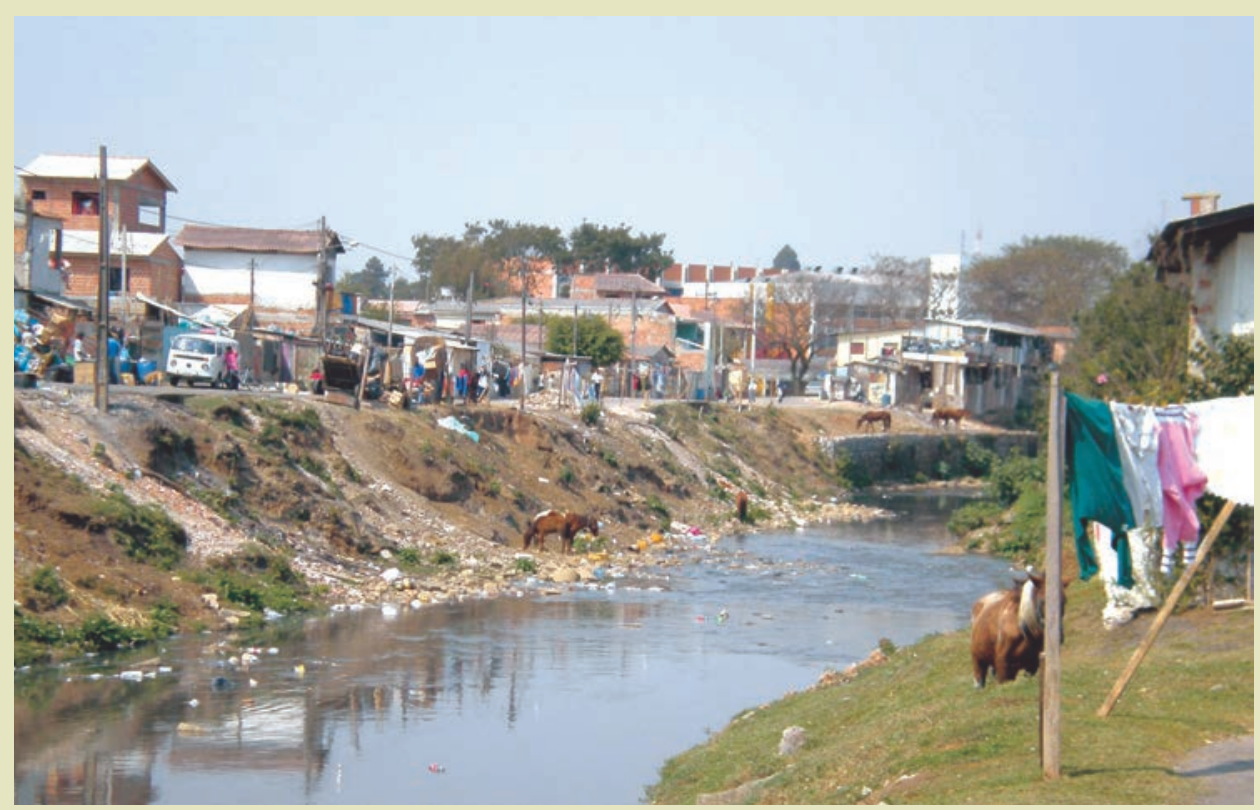

\section{RESUMEN}

Esta es una discusión teórica sobre la vulnerabilidad social y la construcción de los índices de vulnerabilidad. El ejercicio empírico se llevó a cabo en la ciudad de Curitiba, sur de Brasil. El artículo se basa en dos enfoques conceptuales que revelan la complejidad de este tema, así como de las necesidades básicas para la fijación de prioridades, en términos de acción, la reducción del riesgo de eventos naturales adversos y la distribución de los recursos en la recuperación post-desastre. El contexto urbano es el de las ciudades brasileñas, que destaca las desigualdades en la forma en que los habitantes construyen, utilizan y transforman los sectores urbanos. La investigación que aquí se presenta puede ser contextualizada en un escenario en el que las circunstancias adversas deberían afectar profundamente el desarrollo de políticas públicas urbanas. Su objetivo principal es contribuir a la identificación de parámetros para la canalización de recursos públicos en la preparación para hacer frente a situaciones adversas.

\section{PALABRAS CLAVE}

Vulnerabilidad social, Desastres naturales, Índice de vulnerabilidad, Curitiba.
Informal settlement, Curitiba. Source: Authors archive, Beatriz Hummell, 2007
Beatriz Hummell is a doctoral candidate in Urban Management at the Pontifical Catholic University of Paraná in Curitiba, Brazil. Her main research interests are in disaster diplomacy and humanitarianism, social vulnerability to natural hazards and urban regeneration in slums. Was a visiting scholar at the University of South Carolina and participated in the Munich Re Foundation and UNU-EHS (United Nations University - Institute for Environment and Human Security) 2012 Summer Academy (From Social Vulnerability to Resilience: Measuring Progress toward Disaster Risk Reduction). Currently develops research for her doctora dissertation entitled "Geographies of Solidarity: inequities in priority definition for aid addressing after natural disasters".

ultramari@yahoo.com hummellb@yahoo.com.br 


\section{FOREWORD}

According to The International Emergency Disasters Database, the number of natural hazards in the last decades increased faster if compared with the first decades of the 1900s (EM-DAT, 2009). Similarly, Munich Re Group (2003) data show that the economic losses related to disasters also have increased since the 1950s. Other studies, developed according to different methodologies have stressed similar concerns. Data showing and highlighting the increase of disasters are, in fact, recurrent in the scientific production that discusses contemporary social and urban problems. It highlights that the occurrence of disasters is an important factor to consider when formatting urban management initiatives. Additionally, the United Nations Development Programme (UNDP) states that, in the last 25 years, not only the number of reported natural disasters but also their impacts on human and economic development worldwide have increased, reducing gains obtained during a period of relatively economic success. "It is troubling that disaster risk and impacts have been increasing during a period of global economic growth" (UNDP, 2004, p. I I).

Natural hazards may occur regardless of social stratification, however, their impacts affect differently among these very same specificities, enabling damages to increase or diminish their temporalities. Empirical and scientific observations also confirm that lower income levels populations are often repeatedly affected by recurrent hazards, pointing out the relevance of social and economic parameters on the vulnerability concept. Currently it is largely accepted that different social levels react differently when exposed to the same hazards. By adding the complex social differences to a wide concept such as Beck's (1992, 2006) risk society, vulnerability would act as a result of contemporary economic and technological development but also of discrepancies in the outputs distribution of this very same development. Other concepts have so been repeatedly discussed, but mostly in a palimpsest way: instead of eliminating preterit hegemonic ways of understanding natural disasters impacts, they were readjusted in new and more complex hierarchies of importance.

This article is based on such conceptual bias, stressing a close relation between impacts caused by natural disasters and social characteristics of those who are submitted to them. If impacts are now considered according to multiple perspectives (a long desired comprehension), prevention still depends on a limited social memory. In fact, because social vulnerability may be understood as a "dormant phenomenon till a calamity occurs," it is still more easily related to risk management situations and hardly taken as a pre-existing condition that shapes suffering and recovery ability. Although progress can be present in the scientific discussion on adverse phenomena - confirmed and fostered by an increasing scientific discussion on the theme -, public policies seem reluctant in taking new approaches in their programs. That was the situation observed by these authors in their studies in Brazilian municipalities under strenuous conditions due to floods and landslides (common disasters in the country during summer season). Case study presented here is an example. It takes place in the city of Curitiba, located in the southern region of Brazil, with 2 million inhabitants and internationally known due to its urban management experiences and a better quality of urban life if compared with country's average. These positive aspects notwithstanding, social inequalities are for a long time present in the city. Lack of historical data does not allow to attest that number of disasters, percentage of affected people and economic losses are increased in the last decades. Therefore, common sense insists on predicting bleaker scenarios for the city. Methodology adopted in this case study overlays the areas most affected by natural hazards and socio-economic indicators spatially. This methodology is based on the data available and developed to distinguish the city's districts according to their vulnerability index. It also stresses the importance of dealing with public policies spatially. This type of approach is rarely seen in Brazil, even considering that Brazilian cities 
have clearly delineated social and environmental compartments. Time frame considered for this analysis is limited to 2003-2008. Longer periods of analysis would certainly provide more solid results. However, the previously intended time frame of 10 years had to be shortened either because of data unavailability or different methodologies used to collect them. Nevertheless, this six-year period provides rich information on the topic discussed here due to its particularity in terms of annual recurrence of intense adverse natural phenomena in the city. Geographical scope of the research refers to the entire territory of the city $(430,9 \mathrm{sq} . \mathrm{km})$ according to its 75 districts that represent not only administrative units but also specific territories with particular social and economic scenarios.

\section{BRAZIL: A CONTEXT OF ADVERSITIES}

Human and economic losses caused by natural disasters call for a combined and complex action in terms of prevention, risk reduction, emergency procedures and reconstruction practices. This is another recurrent observation among concerned scientific literature but that still rests unapprehended by different government levels. Despite an almost general acceptance that natural adversities impacts go far beyond the complexities of emergency responses, important aspects involving a myriad of stakeholders still lack understanding. There is thus a gap between what is conceptually long agreed and what is definitely observed and implemented by governmental agencies. Ideas such as let's not only rebuild, but build it better, preventing is easier than rebuilding, vulnerability should be socially understood, among other examples, still remain heard as repeated mantras but hardly implemented ones. Globalization of solidarity, characterized by an intensive exchange of practices and by a struggle for more transparency, seems to help in this necessary transformation. However, so far, this article is still contextualized in a reality where gap between the discourse and the action is persistently clear.

According to Nunes and Kobiyama (2006), the increase of reported disasters can be related to a number of factors, such as the population growth, social and territorial segregation, accumulated resources in danger areas, progress in communication media, and global changes. This phenomenon also can be more specifically related to the global warming process and climatic changes (IPCC, 2007). If the causes of increasing trends of natural disasters are to be related to a number of different factors, current scientific production seems to focus its main concern on the social aspect, which is decisive to understand natural hazard impacts.

Yet considering the complexity involving the increasing number of disasters and the increasing impacts they impose, this paper concerns the need for cities to adopt planning preventive tools and comprehension of social aspects (and vulnerability) spatially in order to reduce risks and mitigate natural adversities impact. Indeed, many authors quote the cities' occupation dynamics and urban growth as important facts to understand social systems and the social and environmental vulnerability related to natural hazards (Santos, 1996; Rolnik, 1997; Giddens, 2000; Hogan et al 2000; Kasperson \& Dow, 200 I; Mattedi \& Butzke, 200 I; Carvalho, 2006; Maricato, 2006; and Marandola Jr. \& Hogan, 2006). Although cities may be considered both the cause and the scenario of devastating phenomena, not much progress has been identified in terms of their local policies apprehension.

The intense and fast urban occupation in Brazil, especially in the 1970s trough 1990s, was caused by many facts such as a) Mechanization of rural production procedures resulting in migration of countryside populations to cities and b) Generalized crisis in the production and consumption systems with impressive layoffs and no generation of new compensatory job posts. Urban expansion is basically a result of I) An impressive official conversion of rural areas into urban lots, reserved to those who can afford this product, 2) An even more 
impressive production of irregular or illegal division of land properties, and 3) A complex process of squatting environmentally fragile urban compartments. These three factors constitute the synthesis proposed by Milton Santos (1993) in his discussion on Brazilian urbanization process: social division of land and sprawl.

The large amount of unqualified workers available in urban centres triggered low wages, precarious working conditions and informal work. Generalized impoverishment pushed low-income families to distant and never ending suburbs, with no basic infrastructure and disrespect to federal and municipal land use regulations. Resulting illegal settlements occupied areas unfit for development, such as riverside strips (with the reduction of essential riparian woods), environmentally protected or fragile areas, and highly descending slope areas with no proper soil engineering correction, among others. At the same time, municipalities can hardly cope with the responsibility to correct resulting risk situations. In fact, lack of basic services and infrastructure imposes an additional burden to a population already overexposed to natural and social contingencies: non-paved road system or the lack of rain water drainage network causes or aggravates floods, lack of garbage collection services obliterates existing water and sewage pipes and natural hydrological flows, and poor sanitary infrastructure system in high urban densities lead to alarming public health problems. Although these negative premises are commonly taken as a general factor for the Brazilian cities, they should be considered according to specifications of different parts of the cities' territory. As a matter of fact, factors such as land occupation patterns, population income and infrastructure availability should be considered in public policies.

Despite recent positive changes observed in Brazilian cities in terms of housing programs for low income families and financial resources availability for funding urban basic infrastructure, larger parts of the population still face the impacts of its historic deficits of urban infrastructures and urban land misuse. Besides, some well-intentioned governmental programs, such as those of large low income housing programs, made possible by the current national availability of resources, may also generate externalities that aggravate long observed vulnerabilities.

Current urban policies in the country, by recognizing social and financial limitations to transform entire cities, have channelled efforts to more pragmatic solutions comprehending acupunctural interventions, legalization of squatted areas, and maintenance of original people in their occupied lots (Ultramari, 2006). If this approach may be considered appropriate mostly because of legal property rights grants, it does not fully eliminate the submission of large groups of the population to the immediate impacts of natural disasters. Once financial resources become available for improving conditions in informal settlements, property right documents are granted, allowing families to stay in their original areas. A few urban infrastructure works are done, but the risks to natural adversities are not entirely eliminated.

In the last five years, Brazil has embarked in a non-precedent economic rise with immediate transformation in the way its cities are occupied. Legal land market has, in fact, boomed in Brazilian cities, following the decision of federal and local governments to launch massive low-income housing programs. Lower income levels of Brazilian population, which were previously marginalized, are now part of the consumption market. This new occupation dynamic certainly increases pressure on the limited offer of land made available by planning guidelines. At the same time, considering that government programs that require relocation of families from risky areas need availability of nearby land to do so, lacking of urban areas fit for development is now a bigger issue. For the first time in recent Brazilian urban history, limitations for implementing social housing programs concern not only financial restrictions and speculative behaviours, but also physical unavailability of proper land. This 
new situation indicates a problem that has unexpectedly forced national urban planning and management to be more flexible in their parameters of proper and safe land. Irony now takes place in the construction and transformation of our cities: if, in the past, risks were triggered by illegal and informal land occupation, at present, this phenomenon may take place because of official determination and technical orientation.

In case this complex reality is considered, vulnerability easily proves itself not only related to social parameters but mainly by inclusive and affirmative policies.

\section{NATURAL HAZARDS AND VULNERABILITY}

The aforementioned background confirms the idea of a wider concept of vulnerability to natural disasters. Certainly, social, community, political, cultural, and economic aspects play decisive roles in its definition side by side to natural

phenomena. This is, in fact, a conceptual approach already largely adopted by the scientific milieu and that has been clearly defined by the distinction between the Theory of Disasters and the Theory of Hazards. These theories attest two traditional analytical formats. The first one is mostly aware of geographic aspects, such as dimension, causes, and typologies of natural phenomena. The second one conducts its investigations mostly referring to more socially elaborated analysis to understand adverse natural phenomena. From a limited mono-disciplinary approach, the concept of vulnerability has been driven to a wider understanding, with several sciences playing a distinctive and collaborative role (Thouret \& D’Ercole, 1996).

The research presented in this article is related to the Hazards Theory, considering it as its main reference and understanding urban occupation dynamics (presented above) as a fundamental factor to consider lower income levels of the population as the most vulnerable to natural disasters' effects. These populations, usually living in risk areas and relying on their low incomes to cope with adverse situations present a limited response capacity. Alternatively, external governmental and non-governmental agencies become the sole real possibility to mitigate impacts. Deschamps (2004) empirical research reinforces the idea that "There is a strict relation between the placement of the lower levels of the population and those areas characterized by recurrent natural adverse factors. The socially vulnerable populations are placed in environmentally vulnerable areas" (p.104).

This assumption exemplifies a multitude of studies that recognize disasters can no longer be understood through the lens of the nature's will or through the restricted vision of natural sciences alone. Quite the contrary, it calls for the dialectics announced by Hewitt's (1997) and Blaikie et al (1994) in the construction of the idea of social vulnerability. The origins of the concept of vulnerability may, in fact, blur the idea we have of it today. Introduced as a scientific field of research connected to the hazards and disasters phenomena, it still shifts from a more natural to a more social approach. Back in the 1970s, O' Keefe et al. (1976) radically proposed to take the naturalness out of natural disasters, advocating that socioeconomic factors were the causes for natural disasters (a conclusion taken from an empirical study proving that the larger amount of human losses caused by natural disasters is confirmed in poor countries). Chambers ( 1989 ), despite agreeing with the fact that people present specific abilities to cope with exposure to natural adverse phenomena, argues that vulnerability results from both natural and social risk, opening the opportunity to accept that social vulnerability has, in fact, multiple origins in terms of scientific fields, either in social or natural sciences, and so is expected to be presented according to different approaches.

M 69 REVISTA M VOL. 10 No.1. ENERO-JUNIO 2013 • FACULTAD DE ARQUITECTURA • UNIVERSIDAD SANTO TOMÁS COLOMBIA 
Urban social factors - income, community representation, educational indicators, demographic rate, among others - are generally taken as a very broad concept, but immediately reveal tangible aspects of the population in terms of financial conditions to respond positively to basic needs in cities. In fact, these are crucial aspects to define social vulnerability. At the same time, in the case of emergency situations, other components enrich the idea of social characteristics. That is the case of governmental and non-governmental institutional frameworks available to provide emergency responses, implement recovery works and establish prevention procedures. The city of Curitiba has different territorial compartments according to socio-economic patterns, which reflect differences in the population's ability to react to and recover form disasters. However, the entire city, regardless of its social disparities, is trated in a relatively homogeneous way by disaster prevention and recovery policies.

This combination of factors confirms the complexity of the social vulnerability concept expected to be revealed in the empirical study and also allows identifying an overlay of a concentration of low social indicators and the number of natural disasters per district. Case study in Curitiba also confirms that current social indicators have a close relation with them. In Curitiba, as well as in other Brazilian medium and large cities, 1970-1990's poor migrants were puched to occupy areas unfit for development because of the high land price in proper areas. This situation is recognized recurrently among authors who discuss urban inequalities in the context of Brazilian cities. Rolnik (20 I I) perhaps synthesizes these ideas by recalling that

(...) There are ways of intervening in order to improve terrain stability, drain water, slope reinforcements, that are ways of intervening in order to improve safety and management of a certain places so that even at risk situation deaths are avoided. But the main question is that nobody lives in a risky area because they choose to or because they are dumb... People live in a risk area because their income doesn't give them a choice. We are talking about workers whose income does not allow either buying or renting a place to live in a proper area. ... There is no point in palliative measures here and there if we do not take decisive action: where are located areas proper for occupation that will be designated to low income population? (Translated from the Portuguese).

Such reality may be referred to the pressure and release model as announced by Blaikie et al. (1994), reformulating what had been previously identified by Turner et al. (2003). The model proposed by Turner et al (risk hazard model) understands impact of hazards as a result of the exposure to a hazardous phenomenon and of the sensitivity of a community exposed. However, authors do not make clear what or how hazard impacts are amplified or attenuated. The model by Blaikie et al. stresses the progression of vulnerability according to the relation between four main components, three socially constructed and one naturally built: root causes, dynamic pressures, unsafe conditions, and the natural hazard itself. In the case of Curitiba, these four components can be understood as follows. Root causes can be translated into the economic and demographic features of the districts in the city, each of them presenting specificities in their average income, unemployment rate, and demographic indicators regarding the number of people per family and household. Dynamic pressures may indicate the migration process observed in the city confirming at least three main inhabitant groups: those who arrived in the turn of the $19^{\text {th }}-20^{\text {th }}$ centuries; those who arrived in the rural urban migration flux of the 1970s and 1980s and still able to afford propper but distant areas of the city or of its metropolitan region; and finally, those who still arrive, with low income, and occupy inadequate suburb areas of an already large agglomeration. As a rule, these two social components - root causes and dynamic pressu- 
res - present a close relation with the distance from the city's central areas: the further we go, the worst social conditions are presented. This is, in fact, a pattern in Brazilian cities, where central areas differ in terms of historical occupation, provision of infrastructure, urban infrastructure quality, and income from those areas occupied in the most recent decades, more precisely after the 1970s, when the urbanization process expanded in the contry. Third, Blaikie et al's component - unsafe situations - is to be observed mostly in summer time during the rainy season and the resulting floods. Illegal settlements along rivers or in areas considered unfit for occupation by planning guidelines, but still an affordable choice for lower income classes, are among the areas more vulnerable to such adversities. Finally, in terms of the natural hazard itself - the fourth component, it is important to recall that impermeabilization of urban land resulting from a rising population growth of $1.3 \%$ per year and a never seem civil construction sector expansion, have imposed the reduction of naturally permeable areas. Deacreasing the amount of permeable soil in a high-density area overcharges the drainage systems, which many times fail causing floods in urban areas. This issue is tangled with other problems commonly found in Brazilian urban areas, such as poor garbage collection services, lacking sewer infrastructure, among others, that increase the probability and consequences of flooding, especially during summer rain season.

It seems that models to establish components of a comprehensive concept of vulnerability and indicators to geographically measure impacts of adverse phenomena are under constant criticism and, paradoxically, an object of recurrent practice, both at public policy agencies and scientific production levels. Undoubtedly, despite conceptual limitations of these methodological tools, they remains a reference for public management concerning the most sensitive groups in emergency situations. In the case study presented here, pragmatism imposed submission to data available: number of occurrences (floods) per district per year and social indicators gathered to summarize a hierarchy of income levels' emergency response ability per district. By adopting such approach, we avoid common criticism to the construction of the concept of vulnerability by adding probably more adequate indicators but with difficulty in their measurements. Besides, the approach adopted here considers the fact that statistics concerning geographic and social concentration of floods in the city of Curitiba are taken as a result of I) Social structures and processes (either by the lack of propper infrastructure or by the occupation of environmentally fragile areas), 2) Different responses to recovery according to different socioeconomic profiles (poor populations rely more on immediate public action than those who can afford individualized solutions), and 3) Physical features of the municipal terrain (some areas are more subject to floods than others). As a matter of fact, the case of Curitiba, which could be taken as a parameter for other Brazilian cities, overlaps these three levels of comprehension: unsafe lands are primarily occupied by lower income people, both for historical reasons but mostly because of impositions of segregating practices concerning real estate values. The effort to establish a relation between these levels of comprehension is aligned to what Villagrán de León (2006) considers one of the main current topics in the formulation of social vulnerability: use of models to explain it and the creation of indicators to express it over time and across spaces.

Another conceptual reference adopted in this case study concerns the limited number of indicators used to determine the most and the least affected districts by adverse natural phenomena and the most and the least prepared districts to respond positively to their impacts. It contradicts other analyses such as that developed by Yeletaysi, Sarp et al. (2009), among many other authors, who work with a broader set of indicators to identify poverty. In our case, there is an assumption, based on empirical experience, where it is possible to work with combined indicators such as that used by the municipality of Curitiba to express a social condition or, what interests the most here, a hierarchy among districts of

M 71 REVISTA M VOL. 10 No.1. ENERO-JUNIO 2013 • FACULTAD DE ARQUITECTURA • UNIVERSIDAD SANTO TOMÁs COLOMBIA 
social fragility facing disasters. By proceeding this way, we avoid criticism as that recalled by Villagrán de Léon (2006) who attests an intrinsic difficulty in quantifying vulnerability.

In the other hand, Cutter et al. (2003) use a broader set of indicator to calculate a composite index (Social Vulnerability Index, SoVI) for the United States. By analyzing factors driven by a set of indicators, SoVI allows to identify more specific aspects (i.e. elderly, specific type of industry, race and ethnicity, etc) to be explored by policy makers when thinking about possible tools for empowering populations to better prepare for and recover from disasters. Hummell (2013) shows that SoVI is doable for Brazil at the state level. However, at the present moment there is no availability of such data at the city level.

An important fact to be considered for the construction of a socially sensitive public policy is that certain areas of a city are more likely to suffer from the very same adverse event than others. Appreciation of the case of Curitiba attests that it results not only from different physical features but also from differences concerning its population groups. By doing so, this discussion enlarges the comprehension of Beck's (1992) idea of risk society or even his own concept of risk: society is not only part of the "world's uncontrollability" but also capable of disaster preparedness, mitigation, reconstruction and, most important, understanding who deserves priority in actions depending on limited financial resources.

The case of the city of Curitiba reinforces thus these ideas and confirms the hypothesis that the higher impacts of disasters and the lowest social and economic features are expectedly and almost precisely overlaid. The combination of social and physical aspects reveal a conceptual concern that disasters are hard to be named either natural or human but certainly carries a combination of both (Baker, 1976; Tobin and Montz, 1997).

The understanding that natural hazards cannot be described as consequences of independent natural or human factors but, most likely, as a result of their complex and constant interaction is on the basis of what is described below.

\section{CITY OF CURITIBA: ANALYSIS AND RESULTS}

The method used in the case study is primarily based on the analysis of official data produced by public agencies. According to Brazilian legislation and local institutional practices, incidence of disasters must be reported, properly classified, and publicized. Despite this organizational process of collecting and making information available, as well as an increase in the number of disasters and in the number of impacted areas and people, they are not yet easily spatially understood. It means that civil emergency response agencies or urban management processes still resent planning tools to establish priorities in terms of city compartments and their vulnerability specificities. This absence of spatial comprehension is implied not only in a blurred and generalized view of possible adverse phenomena and their real impacts but also in difficulties to later determine the kind of action needed to each one of the city's urban compartments. In fact, most of the Brazilian municipalities still lack data that considers disasters spatially; the city of Curitiba made progress in presenting this data according to its districts. However, more precise scale, the one that is able to precise impacts in terms of streets and blocks, is still in demand.

In terms of the variables used in the research, two are more representative: a) Natural disasters (number of registered disasters per district between 2004 and 2008), collected by the City's Civil Defence Agency and classified by year and type of occurrence; and b) Population's Quality of Life Index (PQLI) given in percentage and synthesizing a series of 
education, health, housing, safety, and transport indicators. This variable was collected at the Institute of Research and Urban Planning of Curitiba (IPPUC) and refers to 2003. In both cases, data used were the most updated at the moment of the research. Complementary and updated analysis made for selected compartments of the city confirm positive changes in terms of the Population Quality of Life Index. However, it also confirms the persistence of spatial patterns differentiating districts and maintaining the same discrepancies already observed before.

Data concerning disasters are commonly classified in natural, anthropic, and combined by Brazilian Civil Defence Agencies. Despite the fact that such distinction is very subtle in urban areas and not easily differentiated from one another, official data are still organized according to these three typologies. In the case of the present research, the combination of anthropic factors such as the location of urban settlements, techniques of civil construction, density categories, provision of infrastructures, and impermeabilization of land surface patterns intensely shape and graduate impacts imposed by the most recurrent natural adverse phenomenon observed in the city: intermittent floods in selected areas during the three months of summer. Discussion presented here is limited to this kind of disasters (floods) and confirms the inaccuracy in classifying disasters according to independent causes.

In order to make a joint analysis of both indicators (number of disasters and PQLI), each were classified in 5 intervals according to the standard deviation form the sample mean. Qualitative values from I (good) to 5 (bad) were assigned to the intervals. Figures I and 2 show the classification of Curitiba's districts according to the number of disasters and PQLI respectively.

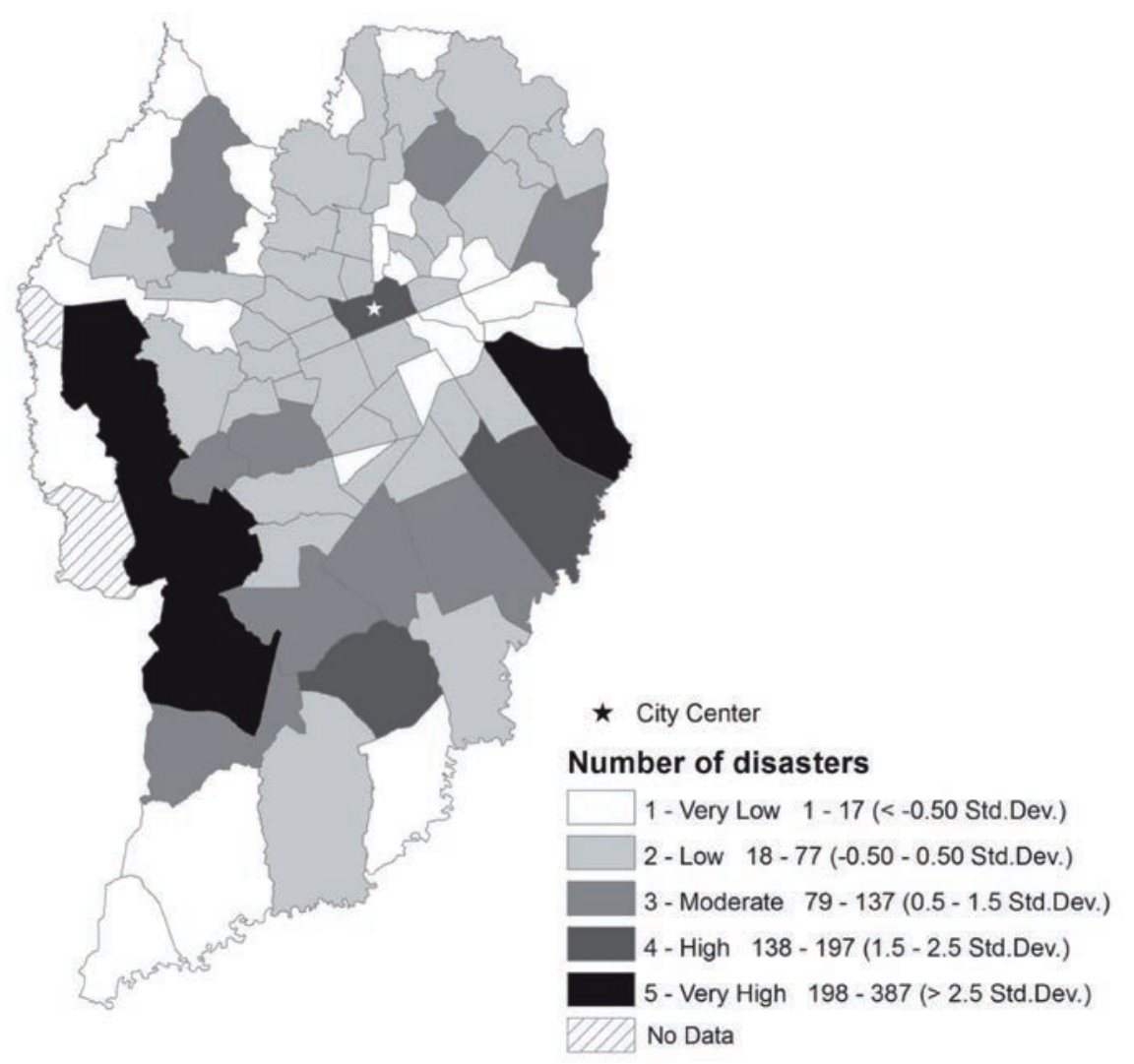

Figure I. Hierarchy of Curitiba's Districts According to the Number of Disasters. Source: Authors. 
Figure 2. Hierarchy of Curitiba's Districts According to the PQLI. Source: Authors.

It is possible to notice in Figure I that most districts present a low or very low number of disasters. The districts that presented a higher numbers of disasters are the city center, a few districts randomly distributed in the north portion of the city and a larger number concentrated in an east-west corridor south to the city center (downtown area). Expectedly, the districts around the city center present lower numbers of disasters. These districts present higher income levels and historically have good infrastructure and development. This pattern is confirmed in Figure 2, showing a very high or high quality of life in most of these districts. The districts further away from the city center present lower quality of life.

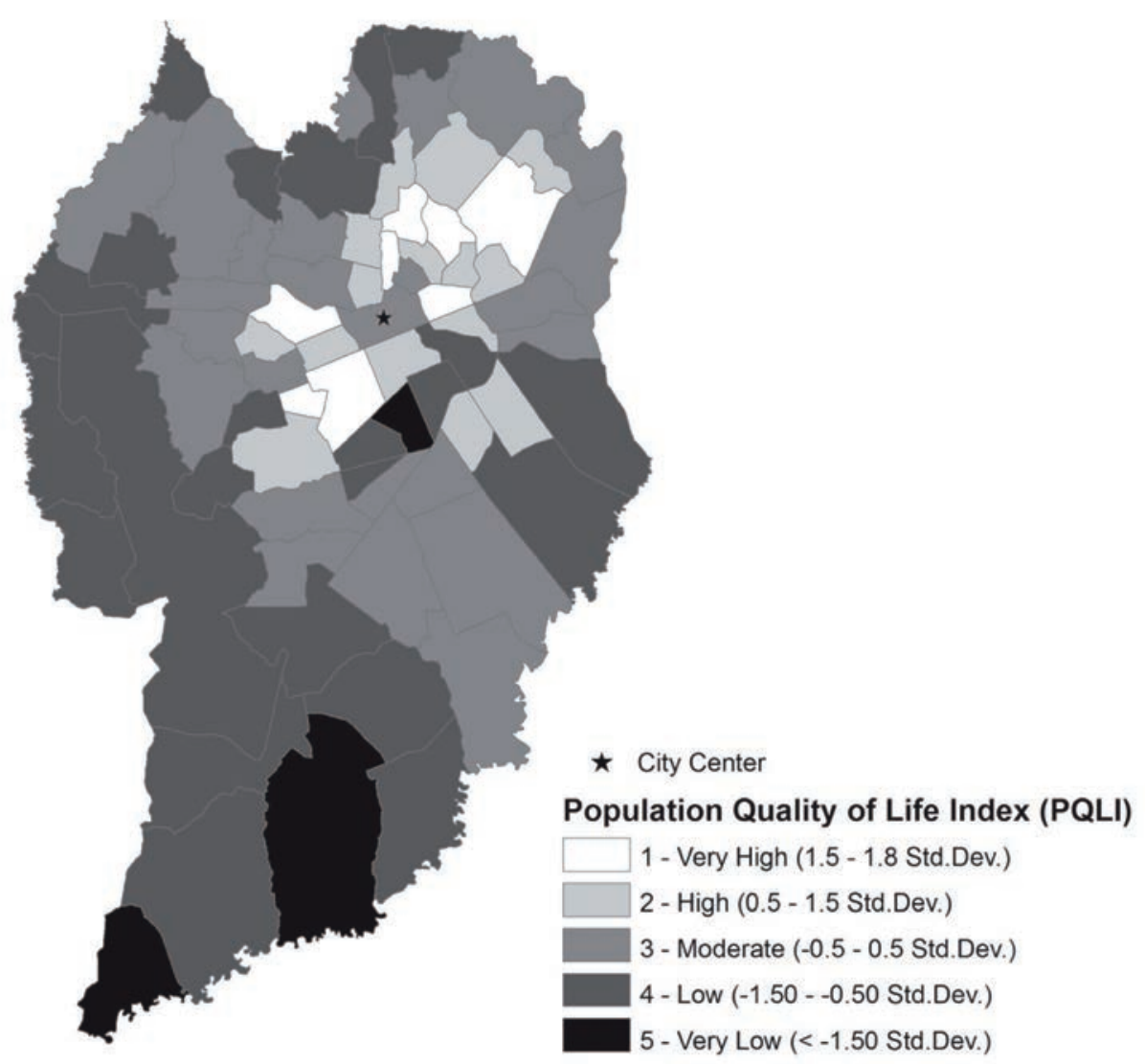

When analysing the information of the two variables simultaneously by adding the attributed qualitative values ( $I$ to 5 ) a new rating scale is created. This new rating scale is here considered representative of the vulnerability of the districts, by combining a social (PQLI) and a disaster (number of disasters) variable. Table I illustrates how the qualitative values of the variables were combined. 
Table I. Vulnerability scale resulting from the combination of the attributed qualitative values of the number of natural disasters and PQLI. Source: Authors.

\begin{tabular}{|c|c|c|c|c|c|c|}
\hline & \multicolumn{5}{|c|}{ Population Quality of Life Index } \\
\hline & & $\begin{array}{l}\text { Very } \\
\text { High - } \\
1\end{array}$ & ${ }_{2}^{\text {High - }}$ & $\begin{array}{l}\text { Moderate } \\
-3\end{array}$ & $\begin{array}{l}\text { Low - } \\
4\end{array}$ & $\begin{array}{l}\text { Very } \\
\text { Low - } \\
5\end{array}$ \\
\hline \multirow{5}{*}{ 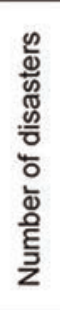 } & $\begin{array}{l}\text { Very } \\
\text { Low - } 1\end{array}$ & 2 & 3 & 4 & 5 & 6 \\
\hline & Low - 2 & 3 & 4 & 5 & 6 & 7 \\
\hline & $\begin{array}{c}\text { Moderate } \\
-3\end{array}$ & 4 & 5 & 6 & 7 & 8 \\
\hline & High - 4 & 5 & 6 & 7 & 8 & 9 \\
\hline & $\begin{array}{l}\text { Very } \\
\text { High -5 }\end{array}$ & 6 & 7 & 8 & 9 & 10 \\
\hline
\end{tabular}

\begin{tabular}{|c|c|}
\hline \multicolumn{2}{|c|}{ Vulnerability scale } \\
\hline 2 and 3 & $\begin{array}{l}\text { Very low } \\
\text { vulnerability }\end{array}$ \\
\hline 4 & Low vulnerability \\
\hline 5 & $\begin{array}{l}\text { Moderate } \\
\text { Vulnerability }\end{array}$ \\
\hline 6 and 7 & High Vulnerability \\
\hline 8 to 10 & $\begin{array}{l}\text { Very High } \\
\text { Vulnerability }\end{array}$ \\
\hline
\end{tabular}

After this classification, it was possible to visualize a spatial representation that gathers both variables simultaneously (registered number of disasters and PQLI) and then to establish a vulnerability scale, depicted in Figure 3. Such representation confirms that a) Neighbouring districts perform similar results, and b) Distinction between central and peripheral districts is clearly observed.

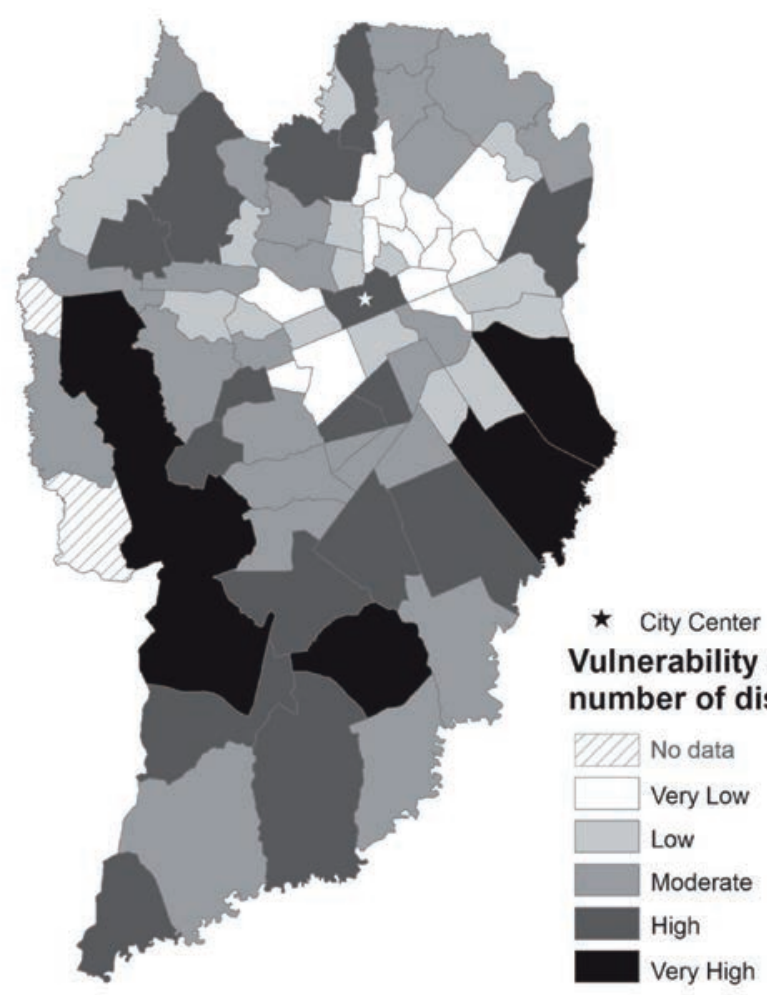

Figure 3. Curitiba's district classification according to the vulnerability scale. Source: Authors.

M 75 REVISTA M VOL. 10 No.1. ENERO-JUNIO 2013 • FACULTAD DE ARQUITECTURA • UNIVERSIDAD SANTO TOMÁS COLOMBIA 
Districts presenting low and very low vulnerability are generally located in the surroundings of city center. This can be explained by the history of this part of the city territory, which has been occupied mainly by higher socioeconomic level populations. It also confirms that safer areas were first occupied, leaving those considered under risk to migrants arriving in the 1970's - 1990's demographic boom or simply to those who could not afford overpriced center urban land. It is important to stress that the areas in the center portions of the city were not turned safe by infrastructure interventions. Quite the contrary, they present almost no limitations in terms of unstable terrains, slopes, or high concentration of river channels. Mostly recent occupied areas either dependent on such infrastructure implemented by local government or are simply left to be occupied under risk.

Districts with moderate to high vulnerability do not present specific patterns of concentration in the territory. They are, in fact, the most recurrent situation, establishing an average where disasters are confirmed only when very serious adversities happen (according to historic data, in average every 20 years) but still very dependent on the role of local government agencies.

Despite the aforementioned facts, by drawing an east-west line along the middle of the map, it would be possible to observe a concentration of least vulnerable districts in the upper portion of the map, whereas the higher vulnerability districts are concentrated in the southern portions of the city. Again, this fact may be related to the history of the territory's occupation: selection of safer and infrastructured areas by those who first settled (a long and slow process of urbanization till late 1960s) among an occupation that would sprawl to distant, improper, and metropolitan terrains.

Final analysis reveals that 13 districts or $18 \%$ of the total have very low vulnerability (additive scores of 2 and 3, Table I), accounting for the best situation in both variables. Four districts, or $5.5 \%$ of the total have very high vulnerability (additive scores of 9 and 8 - there were no 10 scores), presenting a bad situation in both variables.

All these facts allow the conclusion that in a great number of cases, the districts classified as having good quality of life are related to lower registered numbers of disasters. On the other hand, districts classified as having low quality of life are related to higher registered number of disasters,

Considering these observations, it is possible to understand that the populations with lower PQLI are more vulnerable to natural hazards than those presenting higher PQLI. This information allows the return to the working hypothesis announced earlier in this article that lower income levels of the population are more recurrently affected by disaster, and that the type of areas occupied by this population is related to their higher vulnerability. This being confirmed was so reiterated in the final results of the research that authors now believe it should be only named assumption due to its very clear evidences.

\section{FINAL REMARKS}

A conceptual review on social vulnerability and efforts to measure it are discussed in this paper. The case study presented here is submitted to explicit methodological limitations for apprehending social realities in abstract representations such as numerical indicators and 
maps. Despite the confirmed possibility to rely on the vulnerability rating as a parameter for the development of public policies in the city of Curitiba, it leaves room for controversies concerning variables to be considered and the way they are overlaid and finally analyzed. Despite its significance for urban planning, it reinforces unavoidable generalizations of specific situations (in this case, made at the district level), recalls the multitude of variables influencing final results, demonstrates recurrent ideological approaches in the selection of parameters to be taken into consideration, and confirms a submission of the researcher or policy maker to data availability. If this complex situation leads to reconsider the search of precise hierarchical definitions of spatial compartments in terms of risks, the extreme situations, those that interest us most (districts with higher vulnerability) are believed to be detected in a more accurate way. Such contribution, made possible by the definition of a vulnerability index, also may serve as an instrument of public policies concerning different needed governmental or community actions facing risk reduction plans or emergency procedures. Despite generalizations because of the geographic scale adopted (districts), it may constitute a primary planning tool. Otherwise, much room is left to the investigation of particularities at a more intra-urban scale, considering existing differences inside the same district.

Results presented in this research were not expected to point out other factors related to the concept of vulnerability, such as different capacities of the different levels of the population to reduce risks and to respond to disasters according to their institutional and local organizations. Therefore, there is an assumption that it is partially implicit in socioeconomic profiles described in the synthesis brought by the Population's Quality of Life Indicator (PQLI). Constraints and distinguished abilities to establish either formal or informal civil organizations to present demands are to be differently detected in territories classified either as the most or as the least vulnerable ones. Socio-economic scenario worked in this research certainly indicates the existence of an overlay of unequal access to urban services and infrastructure (education, health, housing, safety, and transportation), unequal conditions to respond to emergency situations, and unequal conditions to postulate for structural changes. If this triple overlay is somewhat a synthesis of different vulnerabilities, it still recognizes the existence of a city far from the dual visualization (rich and poor) proposed by Castells (1989) or Mollenkopf \& Castells (199I) but closer to a more encompassing one, such as that formulated by Marcuse's quarters (1993). From a dual city of rich and poor, overlays worked in this research indicate an urban occupation characterized much more by a profusion of situations, agents, and abilities to cope with adverse natural phenomena.

If the assumption that different socioeconomic levels are affected differently by natural disasters is largely taken into consideration at conceptual discussion, urban management practices are hardly familiarized with these particularities in their own territories. It draws the attention to the fact that preventive actions are not only needed but also must adopt a profound fractal vision of the city.

\section{REFERENCES}

Alexander, D. (2003). Terrorism, Disasters, and Security. University of Wisconsin. Journal of Prehospital and Disaster Medicine. 2003; 18 (3): I65-169.

Beck, U. (1992). Risk Society - Towards a New Modernity. London, Sage Publications.

M77 REVISTA M VOL. 10 No.1. ENERO-JUNIO 2013 • FACULTAD DE ARQUITECTURA • UNIVERSIDAD SANTO TOMÁS COLOMBIA 
, Ulrich. (2006). Living In the World Risk Society. British Journal of Sociology Centennial Professor. London School of Economics and Political Science: A Hobhouse Memorial Public Lecture given on Wednesday I5th February 2006, London.

Blaikie, P., T. Cannon, I. Davis \& B. Wisner. (1994). At Risk: Natural hazards, People's vulnerability, and disasters. London, Routledge.

Carvalho, I. M. de. Globalização, Metrópole e Crise Social no Brasil. (2006, maio). Revista Eure. Vol. XXXII,95, 5-20, Santiago do Chile,.

Castells, M. (1989). The Informational City. Oxford: Basil Blackwell.

Curitiba. Agência Curitiba de Desenvolvimento S.A. (2007). Available in: <http://www. agencia.curitiba.pr.gov.br/publico/conteudo.aspx?codigo $=4 I>.03 / I 0 / 2009$. Accessed 23 March 2011.

Cutter, S.L., J.B.Boruff and W. L. Shirley. (2003, June). Social Vulnerability to Environmental Hazards. Social Science Quarterly, 84, (2) 596:606

Deschamps, M. (2004). Vulnerabilidade Socioambiental na Região Metropolitana de Curitiba. Phd Thesis: Programa de Doutorado em Meio Ambiente e Desenvolvimento da UFPR, Curitiba.

EM-DAT, Emergency Events Database. (20II). The OFDA/CRED International Disaster Database. Available at <http://www.emdat.be/natural-disasters-trends>. [Accessed 23 March 2012].

Giddens, A. (2000). Sociologia. 2. ed. Lisboa: Fundação Calouste Gulbenkian.

Hewitt, K. (1997). Regions of Risk: A Geographical Introduction to Disasters. Essex, Longman.

Hummell, B.L. Hazards, Social Vulnerability and Resilience in Brazil: An Assessment of Data Availability and Related Research.

IPCC - Intergovernmental Panel on Climate Change. Summary for Policymakers. (2007). Climate Change 2007: The Physical Science Basis. Contribution of Working Group I to the Fourth Assessment Report of the Intergovernmental Panel on Climate. Cambridge University Press, Cambridge, United Kingdom and New York, NY, USA.

IPPUC. Curitiba em dados. (2007). Available at: <http://ippucnet.ippuc.org.br/Banco dedados/Curitibaemdados/Curitiba_em_dados_Pesquisa.asp >. [Accessed 22 October, 2009].

Kasperson, R. E.; Kasperson, J. X; Dow, K. (200I). Vulnerability, equity, and global environment change. In: Kasperson, R. E; K., Jeanne X. (Ed.). Global Environmental Risk. Londres: United Nations University Press, p. 247-272.

Marandola Jr., E.; Hogan, D. J. (2008). As dimensões da vulnerabilidade. São Paulo em Perspectiva, São Paulo, Fundação Seade, 20, I, 33-43, jan./mar. 2006. Available at <http:// www.scielo.br>. [Accessed 3 August, 2010]. 
. (2004, jul/dez). Natural Hazards: o estudo geográfico dos riscos e perigos. Revista Ambiente \& Sociedade. 7, 2.

Marcelino, E. V. N.; Lucí H.; Kobiyama, M. (2006). Banco de Dados de Desastres Naturais: Análise de Dados Globais e Regionais. Caminhos de Geografia Uberlândia v. 6, n. 19 p. I30149. Out/2006.

Marcuse, P. (1993, September). What's So New About Divided Cities?. International Journal of Urban and Regional Research. 17, 3, 355-365.

Maricato, E. (1996). Metrópole na periferia do capitalismo: desigualdade, ilegalidade e violência. São Paulo: Hucitec.

Mattedi, M. A.; Butzke I. C. (200 I, Jul/Dez). A relação entre o social e o natural nas abordagens de hazards e de desastres. Revista Ambiente \& sociedade, 9, Campinas.

Mattedi, M. A. (2009). Causas e conseqüências do fenômeno no território. In: Seminário de Estratégia Habitacional de Blumenau e Região. Blumenau, 09 mar 2009. 19 slides. Power-point presentation.

Mollenkopf, J. and Castells, M. (eds). (199I). Dual City: Restructuring New York. New York: Russell Sage.

MUNICH RE GROUP - Munich Reinsurance Group. (2003). Annual Review: Natural Catastrophes 2002. Munique. Available at <http://www.munichre.com/en/publications/ default.aspx $>$ [Accessed 04 February, 2010].

O' keefe, K. Westgate, et al. (1976). Taking the naturalness out of natural disasters. Nature, $260,5552,566-567$.

PNUD. (2008). Programa das Nações Unidas para o Desenvolvimento. Relatório de Desenvolvimento Humano, (2005). Available at http://www.pnud.org.br/ [Accesed 5 November, 20II].

Rolnik, R. (1997). A cidade e a lei: legislação, política urbana e territórios na cidade de São Paulo. São Paulo: Nobel/Fapesp.

. (20I I). Niguém vai morar em área de risco porque quer ou porque é burro. Jornal Brasil de Fato, Jan., I4 ${ }^{\text {th }}$, 20I I. Available at < http://www.brasildefato.com.br/node/5475 $>$. [Accesed 5 November, 20I I].

Santos, M. (1996). A urbanização brasileira. 3 ed. São Paulo: Hucitec.

Swiss Re, (20II). Sigma Journal. Natural catastrophes and man-made disasters in 20I0: a year of devastating and costly events. Available at: <http://www.swissre.com/sigma/>. [Accesed 5 November, 20I I]. 
Thouret, J-C. \& D'ercole, R.(1996). Vulnérabilité aux risques naturels en milieu urbain : effets, facteurs et réponses sociales. Cahiers Sciences Humaines. 32 (2) 96: 407-422. Available at <http://horizon.documentation.ird.fr/exl-doc/pleins_textes/pleins_textes_4/ sci_hum/0I000624I.pdf >. [Accesed 5 November, 20I I]

Tobin, G. A; Montz, B.E. (1997). Natural Hazards: Explanation and Integration. 2 ed. New York: The Guilford Press.

UN/ISDR, Inter-Agency Secretariat of the International Strategy for Disaster Reduction. (2004). Living at Risk: a global review of disaster reduction initiatives. Genebra. Available at <http://www.unisdr.org/eng/about_isdr/bd-lwr-2004-eng.htm>. [Accesed 5 November, $201 \mathrm{ll}$. . 
Ultramari, C; Rezende, D. (2006). Mudanças e Continuidades na Gestão Urbana Brasileira. Revista Paranaense de Desenvolvimento, n.III, p.19-28, jul./dez. 2006. Ipardes: Curitiba, 2006.

UNDP, United Nations Development Programme. (2004). Reducing Disaster Risk: A Challenge for Development. Nova York. Available at <http://www.undp.org/. cpr/disred/documents/ publications/rdr/english/rdr_english.pdf $>$. [Accesed 5 November, 20I I].

Villagrán de Leon, Juan Carlos. (2006). Vulnerability: a conceptual and methodological review. UNU Institute for Environment and Human Security, Bonn, Available at <http://www.ehs. unu.edu/file/get/3904>. [Accesed 8 November, 20I I].

Yeletaysi. Sarp. (2009). A Framework to Integrate Social Vulnerability into Catastrophic Natural Disaster Preparedness Planning. Proceedings of TIEMS 2009 Annual Conference. Istanbul, june $9^{\text {th }}-$ II $^{\text {th }}$. Available at $<$ http://www.gwu.edu/ icdrm/publications/PDF/ Yeletaysi_et_al_TIEMS2009.pdf >. [Accesed I5 December, 20 I I]. 